\title{
Music Making and Ban on Drumming Among the Winneba People of Ghana
}

\author{
Emmanuel Obed Acquah $^{1^{*}} \quad$ Augusta Arko-Mensah ${ }^{1} \quad$ Michael Ohene-Okantah $\mathrm{Jnr}^{2}$ \\ 1.Department of Music Education, University of Education, Winneba, Ghana \\ 2.Department of Music, University of Ghana, Legon
}

\begin{abstract}
The paper reports an ethnographic study of music making and ban on drumming among the Winneba people of Ghana. Despite the volume of research on the use of music for several occasions in the African community, much attention has not been given to the observance of complete silence as part of the life of some African Societies. This paper discusses the place of ban on drumming in a community where music making permeates the lives of the people. It sought to document how the period of silence is negotiated in the contemporary society. Through purposive sampling and snowballing, traditional leaders and priests, members of historical missionary churches, and those of the Pentecostal/Charismatic orientation were interviewed and their activities within the period of the ban observed. Observance of the ban was, however, not uniform among the Christians. While the mission churches have a policy of accommodating local tradition and to observe the ban by reducing the intensity of music making during the period, the Pentecostal/Charismatic churches, however, insist on not observing the ban, because of its association with traditional deities. The paper reveals that though music forms an important part of the life of the Winneba people in Ghana just as most African communities, ban on drumming is not only a belief that had purely been held as a traditional custom from ancestors, it also conveys the principle of silence, which is beneficial to humans in many respects.
\end{abstract}

Keywords: Effutu, ban on drumming, Winneba, social stability

DOI: $10.7176 / \mathrm{JCSD} / 60-04$

Publication date: June $30^{\text {th }} 2020$

\section{Introduction}

In many traditional African societies, music making is generally organized as social event. It is usually seen at public performances where members of a group or community come together for the enjoyment of leisure and for recreational activities. These public performances may include rite ceremony, festival, or any kind of collective activity. In this regard, Nketia (1966) commented on the pattern of musical organization in Africa:

in many parts of Africa, the general pattern of musical organization is one that emphasizes the integration of music with other social and political action or with those activities in which African societies express or consolidate their interpersonal relationships, beliefs and attitudes to life. (p.11)

The integrated process combines singing, dancing, and instrument playing. This music making process consequently provides great sounds, peeling through the entire community as much as those public performances are held. Music making in the traditional Ghanaian community reaches a climax, especially, during festivals. "Festivals have social, religious, and historical functions, which involve almost the total community; and are always great occasions for music making" (Agordoh, 1974, p.51). Apart from the traditional occasions, activities of Christians find music making indispensable. Music making among the Christians involve singing, clapping, drumming, instruments playing amplified with electronic gadgets. These musical activities are very common in Winneba community of Ghana.

It is palpable to say that music making is the soul of Winneba community. Winneba is bred with, traditional musical ensembles as well as youth community choral groups, apart from the church singing groups. Some of these choral groups are Winneba Youth Choir (WYC), Herald Singers, Akoo Show Choir, African Youth Choir, Prophetic Youth Choir and many more. These choral groups are non-denominational and some of them have been at the choral scene locally and internationally within the past twenty years as Amuah and Acquah (2013) reported. There are other denominational singing groups which are also found performing at public functions. Examples of such groups are the Winneba Catholic Youth Choir, Methodist Junior Choir, Presby Youth Choir as well as other adult denominational choral groups. Similarly, there are traditional such as ompe group, apatampa, adzewa, asafo and fontomfrom. All these groups perform at designated functions at both public and private performances throughout the year, and which requires great deal of rehearsals. In the charismatic churches, the story is not different. Singers and bands always perform at church activities, sometimes, throughout the whole week. So, music making is predominant in the entire community in such a way that it has become a cultivated culture.

In spite of the great importance attached to music and music making in Winneba community, the town has some of its traditional occasions, usually reckoned on the traditional calendar, when a temporary ban is placed on drumming and noise making, especially before any major festival. In Ghana, Həməwə of Ga, Kundum of Nzema, 
and Odwira of the Akan are typical festivals, which are preceded by bans ranging from three and six weeks. Though well intentioned, the ban has not gone down well with all sections of the communities in which they have been enforced. Especially, those sections, which insist that the ban has religious intent, have always seen it as an affront to their true freedom of worship.

In Winneba community, there has been a perennial clash between Christian churches, especially the Pentecostal and Charismatic ones with the traditional authorities who enforce the ban (Ohene-Okantah, 2002). This is because the ban on drumming and noise making has a long tradition, and, having once established it, the traditional custodians of the town feel so strongly about it that they want to preserve it at all costs while the Christians are also faced with rapidly changing socio-economic, and socio-cultural nature of societies, thereby raising the question of the ban on drumming and noise making as becoming disruptive to social stability and church growth.

Indeed, in spite of this ban on drumming, music and music making trend throughout the year. There are performances among choral groups, traditional groups and especially, a Music Department of the University of Education, Winneba, situated at the centre of the town where musical productions suffice every week. The questions then arise:

(i) To what extent is music performed at the instance of the ban?

(ii) What sanctions are given to those found culpable of the ban?

Through ethnographic research design, the study sought to answer these questions and concluded on how in the midst of the ban, music making can be made "silently" for the purpose of peaceful co-existence.

\section{Review of Related literature}

2.1 How African Music was injected into the Church

The African response to the denigration and the denomination of traditional culture and religion came in many forms but the underlying unity was the resilience of African culture and spirituality in the quest for expression and self-fulfillment within the structures of local missionary Christianity (Akrong, 2000). This gave birth to local churches that espoused a philosophy of African spirituality. These included the Twelve Apostles, Aladura, African Faith Tabernacle, and Muzama Disco Christo Church. The modus operandi of these churches were the reliance on traditional religious practices and belief systems such as witchcraft, divination and exorcism which though had been outlawed by the mission churches continued to be part of the concerns of the native. "Their mode of worship featured the use of traditional instruments such as bells, rattles and drums, which represented a return to the African conception of worship as a recreational and devotional occasion" (Essandoh, 1998, p. 33). As Nketia (1974) stated, "These are times when members of a group or a community come together for the enjoyment of leisure, for recreational activities, or for performance of a rite, ceremony, festival, or any kind of collective activity" (p. 21).

The schedule of music making is sometimes related to the beliefs of the people. The wishes of the gods they worship or the reactions evoked from the spirits and forces that are believed to play a vital role in the lives of the people, all control when music may be played. It is within the context of such belief systems that bans on music making are legislated.

\subsection{Placement of Bans}

In the $\mathrm{Ga}$ society of Ghana, drumming is banned for some time before the annual festival begins. Amenlemah (2001) talked about some of them:

the Odwira festival is preceded with a placement of a ban on drumming and other forms of noise making. In the Odwira, the ban actually precedes the festival, and the festival itself is characterized with great amounts of drumming, just as it is in the Homswo of the Ga. In the Abisa, also known as Kundum, the ban lasts throughout the festival, and it is a taboo to engage in any form of organized music making during the period of the festival. (p.36)

Indeed, the restriction, however, does not cover Kundum drums; in fact only Kundum drums (drums associated with the festival) are allowed during the period of the ban.

\subsection{Banned Activities}

Activities covered by the ban also vary. "In the Odwira, they include drumming, shouting, hooting and tooting car horns, over-tuning amplifiers and radio sets, whistling, and all forms of noise making "which cause disturbance to the ear" (Annor-Nyarko, 2001, p.27). Consequently, public funerals, which in Ghana are also great occasions for music making, are also prohibited, though not burials. This occurs both in the Kundum and Odwira. The duration and reasons given for the ban also vary with each festival. For the Kundum, the ban starts two weeks before the festival, and lasts for one more week of the actual festival. During the period before the festival, songs that would be sung during the festival are composed and rehearsed in secret. In that sense, the two-week period is the first phase of the festival. For Odwira, the ban lasts forty days before the festival.

The forty-day period before the Odwira festival is termed a time for meditation. As Kate (2013) explained: 
It is intended to afford the traditional authorities and all members of the community a time to meditate and pray, take stock of the past and pray for forgiveness for offences, prepare for the coming year and prepare to harvest new yam. (p.7).

Toward the end of the ban paths to sacred places and groves are cleared to enable the ancestors to come home to join in the celebration of the festival (Adams, 2010).

It is evident that reasons assigned for the ban so far, include, religious/spiritual ones, and have to do with ancestral worship, which is typical of traditional African religion. Yet Etikpah (2015) rationalizes that "the basic principles underlying the institutions of most prohibitions was to maintain the peace during the period" (p. 11). An interestingly pertinent question arises at this point: Is it therefore worthwhile to publicly assault those who violate the ban? To minimize the incidence of violation, and ensure mass compliance, the Nzema people explain that violators of the ban would develop a sore on the leg. This system of intimidating people into conformity is also typical of African societies, though there might actually be a genuine, desirable, and worthwhile, but rather unexplained reason for compliance.

Of all the studies on festivals cited so far, only Kotei (2001, p. 21) mentions, "the placement of ban on drumming" which has become a bone of contention between the custodians and Christian Churches". She explained that as a result of the expansion of the Ga State, and urbanization, people from many tribes and various religious backgrounds now reside in Accra. It would therefore be an infringement of right if they were forced to observe the ban on drumming. She further recommended that the Christian Council of Churches and the custodians of the land should meet to find amicable ways by which they can co-exist peacefully.

\subsection{Music in Festivals of Ghanaians}

Describing the role of music in the Kundum festival of the Nzema of Ghana, Ellison (2002) in an unpublished Long Essay succinctly calls music "the beautiful garment that is used to cloth our annual traditional festivals" (p.8). He further elaborated that when this garment is removed, "our festivals will be naked, and hollow, for there will be nothing spectacular about them that will excite or win the admiration of the people" (p.9). Music brings the people together, reminds them of their common history, vivifies their ritual and ceremonies, helps them affirm their cooperate solidarity to the state and ancestors, and provides avenues for individual and cooperate expression. Music permeates all activities of the festival but for Winneba, music and music making is not done only at festivals but has become part of the daily activities of the community.

\subsection{Early Orthodox Churches}

The early orthodox churches used only the harmonium organ, sang hymns slowly, and scarcely employed hand clapping as a mode of worship. Noise levels were quite low. So even if a ban were in force, no infringement was apparent. Contrary to this, the modern developments in Ghanaian Christianity include the use of loud sounding instruments and equipment and therefore traditional authorities think noise levels are reaching intolerable levels for the period of the ban. So they began insisting on conformity to the ban, but this, some Christian Churches think, is an infringement on their constitutional rights of freedom of worship.

\section{Conceptual Framework}

From the review, a conceptual framework was developed for music and music making in a modern society.

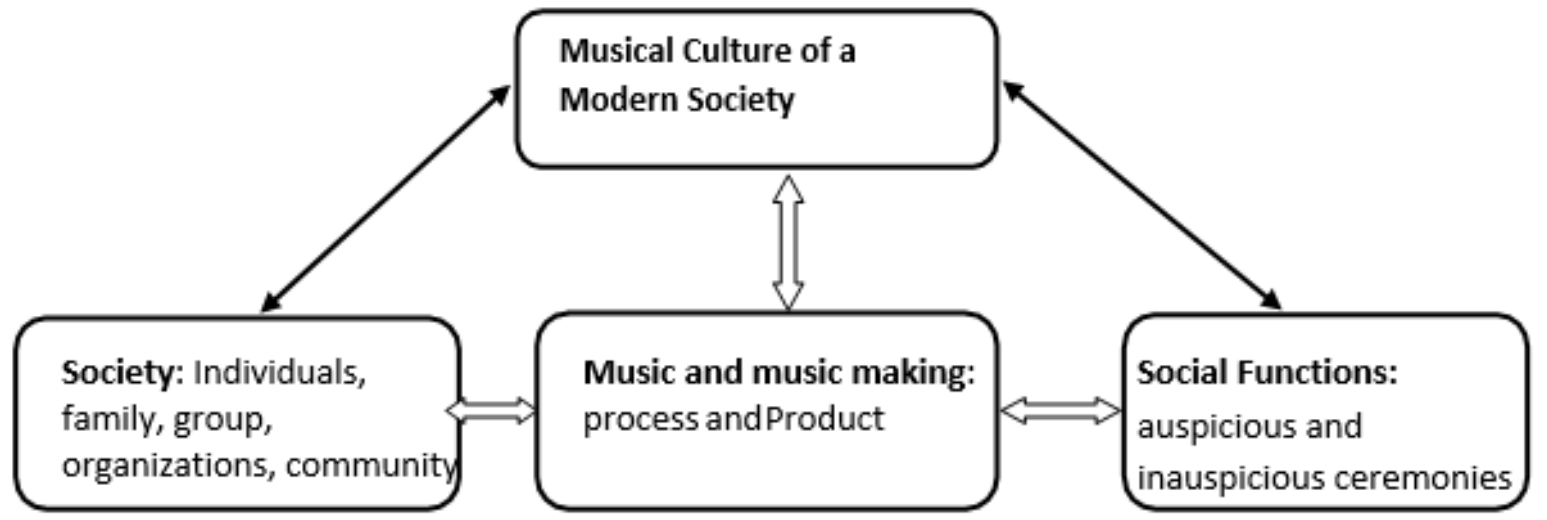

In the conceptual framework, music and music making is almost a universal component of human culture. In this $21^{\text {st }}$ Century, traditional music has grown with embodiment of Western music which basically is both a process and a product of human skill applied to creative activity in the societies. This hybridism of cultivated music in the society has undoubtedly brought a new musical culture where members of the society apply imagination and skill to matter, movement and sound in their worship to express emotions and values and to give one another pleasure. 
Therefore music and music making as applied to the various social functions - auspicious ceremonies and inauspicious ceremonies- within the $21^{\text {st }}$ Century is consciously created, rehearsed and performed, though there exists other spontaneous music making in the traditional society.

\section{Method and Process}

The study was rooted in qualitative research as it was concerned with understanding the social phenomenon from the participants' perspective. Understanding was acquired by analyzing the many contexts of the participants and by narrating participants' meanings for these situations and events. Participants' meanings included their feelings, beliefs, ideals, thoughts, and actions (McMillan \& Schumacher, 1993, p. 373). The design used was ethnography. Ethnography, emerging from anthropology, and adopted by sociologists, is a qualitative methodology that lends itself to the study of the beliefs, social interactions, and behaviours of small societies, involving participation and observation over a period of time, and the interpretation of the data collected (Denzin \& Lincoln, 2011; Reeves, Kuper \& Hodges, 2008; Berry, 1992). Since the ban is a cultural practice, and has social and religious connotations, relevant information had to be obtained from representative of cultural, religious, social, and political leaders in the community. As much as possible, purposeful sampling was employed. By this technique information-rich individual cases were selected for study in-depth because it was needful to understand something about those cases without necessarily having to generalize to all such cases (Patton, 1990 in McMillan \& Schumacher, 1993, p.378). It was done to increase the utility of information obtained from small samples.

Purposeful sampling required that information be obtained about variations among the subunits before the sample was chosen. In this regard one Mr. B, a Security Officer at the Music Department of the University of Education, Winneba, who happened to be a native of Winneba, was very helpful. With his assistance the researchers were able to identify, and locate information-rich key informants, and groups to study. He served as interpreter since some of the informants could speak only the local Effutu dialect. The samples he led us include in our study were very knowledgeable and informative about several aspects of the ban on drumming and noise making in Winneba. This agreed with McMillan \& Schumacher (1993) who asserted that information-rich key informants usually meet such criteria for the phenomenon the researcher is investigating.

Key informants in this category included the Divisional and Sub-chiefs of the Effutu Traditional Area. Others were traditional priests, and selected elders. The chiefs and elders provided corroborative information on the history of the Winneba. Their views on possible approaches to a resolution of the perennial clashes were crucial, being the traditional political heads of Winneba. They also provided information on incidents of violation and actions taken against violators. Information on the rationale behind the ban, its purpose, as well as spiritual significance in relation to the traditional calendar, and associated rituals were elicited from the chiefs, traditional priests and the elders.

Leaders of various Christian Churches were interviewed. These churches were chosen because they had either had clashes with the traditional authorities or not due either to doctrinal position or amenability to or accommodation of traditional cultural practices. The leader of the Triumph Bible Church International was included on the account that he was the current Chairman of the Winneba Ministers Fellowship, which consisted mostly of leaders of young Pentecostal and Charismatic churches, as compared with the historic churches. Two elites within the community were interviewed. They were selected on the basis of their intellectual capacity to analyze and understand broad social issues.

Snowballing sampling, an aspect of purposeful sampling came in very handy. Here, "each successive participant or group was named by a preceding group or individual" (McMillan \& Schumaker, 1993). Opanyin Atobir was identified as one of the oldest persons in the community who could offer information on the history of the ban, but when we visited him, he said, "If you want the history and reason for the ban on drumming and noise making (traditionally called 'nkyen ano siw') then consult the priest of Akrama" (personal communication). Akrama is one of the major deities of the Winneba Effutu people, and ritual to it was performed during the period of the ban. This lead proved particularly useful, and was the first strong indication that the ban had religious intents and purposes.

The design favoured multiple data collection strategies. The basic approach was the use of various forms of ethnographic interviews. The major purpose for choosing this strategy was to gain information about the people's opinions/values, feelings, knowledge, and beliefs with regard to the ban on drumming. The types of interviews included informal conversation interviews and unstructured interview. For the chiefs, and the chief priest, keyinformant interviews were employed. They had information about the history and background of the Effutu and the ban. Particularly, the priests had information, which was otherwise not available concerning the spiritual significance of the ban, as well as meanings attached to accompanying ritual. Since some of the informants are intellectuals, the researchers also employed elite interviews. This included two retired education officers, who were citizens of Winneba and the leaders of Christian religious organizations.

The researchers used both audio tape recorder, and took field notes in recording interviews. Summary observations were written immediately after leaving the site in order to synthesize main interactions. This usually 
suggested more questions, and provided tentative interpretations. Researchers also sampled leaders of youth choral groups and who shared their experiences during the ban on drumming with them. The leader of the pioneer youth choir in Winneba, Winneba Youth Choir was purposively selected. Leaders of the Prophetic choir, Akoo Show choir and the African Youth choir were also selected based on their involvement in local and international functions. Other traditional ensembles were visited during the ban to observe their rehearsals and performances. To ensure validity of the data collected, many more individuals on both sides of the divide were contacted and had friendly chat concerning sanctions usually give to those found blameworthy of the ban. It also sought to investigate the rate at which their music making is done in the midst of the ban on drumming and noise making.

\section{Results and Discussion}

As already stated in the literature, the early orthodox churches used only the harmonium organ, sang hymns slowly, and scarcely employed hand clapping as a mode of worship. Noise levels were quite low then. So even if a ban were in force, such mode of worship was not considered an infringement. Indeed, it became crystal clear that modernity has made all churches including the early orthodox churches use loud sounding instruments and equipment in their worship. With these developments, traditional authorities think noise outputs are reaching intolerable levels for the period of the ban, hence, the insistence on conformity to the ban. As earlier on indicated, some Christian Churches think, it is not unconstitutional.

It was found out that the traditional calendar of the Effutu people, and for that matter, Winneba, starts in May with the Aboakyer festival celebrated on the first Saturday of the month. The calendar is prepared by Nana Gyankumah V, a divisional chief, the regent of the Traditional Area, in consultation with the Traditional Priests. Taking a look at the calendar, the items could be categorized under four main headings: Customs, Rituals, Festivals and Prohibitions. The main concern is the prohibitions but before then a brief discussion of the other items would be in place. Among the Winneba and the Effutu people, there are three types of festivals celebrated in the year. They have the major one which is called the Aboakyer (Deer hunting). The Aboakyer festival marks the beginning of the traditional year. It is this major festival that is associated with the ban on drumming and noise making. Apart from the major festival, they have a secondary festival also called the Akomase, which is also celebrated three months away from the major festival - the major one happening in May, and the secondary one in August.

One significant difference between these two festivals is that while, according to the calendar, the major one takes only one day, the secondary festival spans a little over two weeks. However, because of the popularity of the Aboakyer, other activities are designed a week prior to it. Of course, mention is not made of ritual offerings that go on before the actual day. The minor festivals are all classified as "Yam Feasting". As the name suggests, yam meal is the major food item used at the festivals. They are related to 1) Asafo companies, as for example, Tuafo Fida (Tuafo Friday), a particular god or deity, as Eyipey Out, and Bosomefi. One modern festival that is not mentioned in the traditional calendar is the Masquerade or Fancy Dressing festival. This is also is celebrated in the first month of the year as a purely social celebration.

Making an analytical study of all these festivals of the Winneba people would, indeed, throw much light on their religious life and commitment. Over the years these festivals and attendant rituals have served to hold them together. The rites/rituals include the slaughtering of sheep, and the pouring of libation. The months between November and April are not accounted for on the calendar. Though the traditional ceremonies may have a longer history than Christianity, our interpretation of this gap is to accommodate Christianity.

Enforcing the ban is seen as doing the wishes of the gods and safeguarding the interests of society. It is believed that the ban allows the gods some quiet so they can ensure good harvest in the ensuing year. The ban is also seen, according to the traditional calendar, to be part of the rhythm of society. Breaking the ban is, therefore, disturbing the rhythm of society, and jeopardizing the interests of society, as it would displease the gods, and thus put society at risk.

Like the Traditional Priestess of the Effutu State, indicated:

the ban was authorized by the gods, and instituted by the ancestors, it is in the best interest of

the State. In spite of the impasse, and my desire for peace and prosperity within the state, I

cannot imagine the ban being abrogated, because we came and met it, it is tradition".

Any action taken to halt such "antisocial" behaviour is deemed fit. It is seen as a moral obligation. Such action is regarded as serving two purposes: first, in punishing offenders, the gods would be appeased that appropriate action has been taken; secondly, in consequence, any retributive action that may have come from the gods on account of the violation would be averted. Since it is society, which is eventually put at risk, men must take action in punishing offenders. "In African Traditional Religion, the will of the ancestors and gods is sacred; they are obeyed as religious duty; and whoever attacks anything inherited from the supernatural, attacks the very foundations of indigenous belief system" (Asamoah-Gyadu, 1996, p.18).

There is, therefore, concerted effort to ensure that all inhabitants keep the ban, both natives and settlers. Energetic young men and others who are devotees of the Akrama deity, who sanctions the ban, undertake enforcement. These young men go out as scouts, especially on Sundays to monitor and confront violators, who are 
mostly Pentecostal/Charismatic Churches. If offenders cease drumming the scouts would often go away. More often than not, however, the scouts enter church premises, and begin to collect instruments, which would result in clashes. Under normal circumstances, infringements would first be reported to Nana Gyankuma V before action is taken. Occasionally, he would accompany the scouts to the offender's meeting place.

"A-woo!!" was the first response by Okomfo Ama Takyiwa when the question of what happens to violators of the ban was posed. From the look on her face, that exclamation was an expression of dread, and of possible grievous retribution, undoubtedly from the gods. It is part of African indigenous belief system that supernatural beings, like the ancestors and gods, police the activities of the living, punishing crime and rewarding virtuous behaviour. The gods and ancestors are the custodians of morality, and misfortune is easily interpreted as the consequences of misbehavior and deviation from their standards (Asamoah-Gyadu, 1996, p.16).

Okomfo's immediate memory was of "a church nearby". Apparently, the New Testament Assembly, a Pentecostal Church, which, at the time was worshipping in a classroom of the local Methodist Primary School, about fifty yards away from the residence of Dksmfo. She explained:

I myself had stopped my "this thing" (pointing in the direction of her Radio/Cassette player). I heard "Yee, yee, yee". So I sent one of my priests to inform them that there was a ban on drumming so they must stop. They refused to stop, so I reported the incidence to Nana Gyankuma, the deputy to the Omanhene, who is responsible for these things. He came and collected their drums away. Sometimes the drums are taken to the chief's house, and sometimes to the Urban Council - the traditional authorized body for legal issues. In spite of all that they still persisted in breaking the ban.

At this point Dksmfo gave a sigh of exasperation. Now the violation is worse. They grossly disregard us.

\section{Conclusion}

Though some argued that the ban is merely a social custom, the study revealed that, indeed the ban, as it is observed in Winneba, is a religious custom. Spanning three weeks, it is started and ended with religious ritual led by traditional religious leaders, Priests and Priestesses. The ban is couched in sacred taboo, and therefore belongs to the religious culture of the Effutu people, which reflect their theistic worldview. The Christian attitude toward the ban was seen as a re-surfacing of the negative missionary attitude towards African culture and traditional religion.

Because the ban is religious, violators of the ban are deemed to have offended the ancestors and gods, courting their wrath, and thereby endangering the prosperity, and security of the state. Some of the measures include physical assault and carrying off their drums, summoning them before the Council, and reporting the matter to the District Chief Executive. Attempts at dialogue have not yielded any fruit. However because of the current chieftaincy dispute the ban is not being enforced. The Ban on drumming and noise making in Winneba is a traditional custom of the Effutu people of Ghana. Many Christian groups perceive it as a traditional religious observance. Some traditional leaders and other sympathizers of traditional religion claim it has no religious intent, while others, who are connected with ceremonies involved in it, hold the opposite view. However, the weight of the findings of this study seems to favour an association of the ban with traditional gods and ancestors, thus making it a traditional religious observance, and not merely a "harmless custom". The ban also has implications for Christian theologizing. Even though it is basically idolatrous, it conveys the principle of silence, which is beneficial to humans in many respects.

\section{References}

Adams, F. K. (2010). Odwira and the Gospel: A Study of the Asante Odwira Festival and Its Significance for Christianity in Ghana. OCMS.

Agordoh, A. A. (2005). African music: Traditional and contemporary. Accra: Nova Publishers.

Akrong, A. (1996). The Challenges of the Fourth Republic and Democratic Culture in Ghana, Trinity Journal of Church and Theology, 6(1), $37-48$.

Amenlemah, C. K. (2001). The Abisa Music of the Nzema: Perpetuating Music for Socialization, (Unpublished B.A Music Research Project). University College of Education, Winnaba.

Amuah, J. A., \& Acquah, E. O. (2013). Twenty five years of choral music Performance: Contribution of Winneba Youth Choir (WYC) in the Socio-Economic Development of Ghana. Research on Humanities and Social Sciences, 3(19), 105-112.

Annor-Nyarko, B. (2001). The Role of Music in Odwira Festival: A Case Study of Larteh-Akwapim. (Unpublished B.A Music Research Project), University College of Education, Winnaba

Asamoah-Gyadu, J. (1996). Trokosi and Osu: Cult-slavery in West Africa; A Christian Response. Trinity Journal of Church and Theology. 6(1), $12-21$.

Berry, M. (1992). Contributors to adjustment problems of adoptees: A review of the longitudinal research. Child and Adolescent Social Work Journal, 9(6), 525-540. 
Denzin, N. K., \& Lincoln, Y. S. (Eds.). (2011). The Sage handbook of qualitative research. NY: Sage.

Ellison, E. B. (2002). The role of music in Kundum celebration. (Unpublished B.A Music Research Project), University College of Education, Winnaba

Etikpah, S. E. (2015). The Kundum Festival in Ghana: Ritual Interaction with the Nonhuman among the Akan. Journal of Africana Religions, 3(4), 343-396.

Essandoh, I. K. (1998). Gospel-Highlife: the status and impact of a Ghanaian popular music genre (Unpublished MPhil. Thesis), University of Ghana, Legon.

Kate, G. (2013). A Study of" Kwahu Easter" Festival as a Tourism Hallmark Event (Doctoral Dissertation) University of Ghana, Legon.

Kotei, M. K. (2001). The Role of Music in the Teshie Homowo Festival. (Unpublished B.A Music Research Project), University College of Education, Winnaba.

McMillan, J. H., \& Schumacher, S. (1993). Research in education: A conceptual understanding. New York: Haprer Collins.

Nketia, J. K., \& Nketia, J. H. (1974). The music of Africa. New York: WW Norton.

Nketia, J. K. (1966). Music in African cultures: a review of the meaning and significance of traditional African music. Accra: Institute of African Studies, University of Ghana.

Ohene-Okantah, M. (2002). Ban on drumming and noise making among the Effutus: prospects for dialogue, religious tolerance, and social stability (Th.M. Thesis), International Theological Seminary, USA/Ghana.

Patton, M. Q. (1990). Qualitative evaluation and research methods. SAGE Publications, inc.

Reeves, S., Kuper, A., \& Hodges, B. D. (2008). Qualitative research methodologies: Ethnography. Bmj, 337, 1020. 